\title{
Equilibrium and Kinetic Studies of Liquid Phase Adsorption of Methylene Blue Onto Phosphoric Acid Modified Bambaranut Shell
}

\section{Sciendo}

\author{
Eze Nkechinyere Olivia1, Ejimofor Samuel Adimchinobi², Onuegbu Theresa Uzoma ${ }^{3}$
}

${ }^{1}$ Department of Industrial Chemistry, Faculty of Science, Ebonyi State University, Abakaliki, Ebonyi State, Nigeria

${ }^{2}$ Department of Industrial Chemistry, College of Science, Evangel University Akaeze, Ebonyi State, Nigeria

${ }^{3}$ Department of Industrial Chemistry, Faculty of Science, Nnamdi Azikiwe University, Awka, Anambra State, Nigeria

*Corresponding author email: oliviaeze30@gmail.com

\section{DOI: 10.2478/acmy-2021-0007}

\section{Abstract:}

In view of the global need to curb the effect of contaminants in waste water on our environment, the adsorption potentials of modified carbon from bambaranut (Vigna subterranean) shell was investigated for its efficiency in the removal of methylene blue from waste water. The adsorbent morphology and surface chemistry were established by Brunauer-Emmett-Teller (BET) determination and Scanning Electron Microscopy (SEM), as well as other standard laboratory procedures. The prepared material was used for the uptake of MB from aqueous solution in a batch process, using UV spectrophotometer Model 752 at $620 \mathrm{~nm}$ to analyze for the residual dye concentration. The effect of operational parameters such as contact time, adsorbent dosage, initial dye concentration and $\mathrm{pH}$ were analyzed to determine the factors controlling the rate of adsorption. Results from the study showed that the active carbon prepared was a porous material, with surface area of $193 \mathrm{~m}^{2} / \mathrm{g}$, average pore size of about $10.98 \mathrm{~nm}$, and pore volume of $0.530 \mathrm{~cm}^{3} / \mathrm{g}$. With increase in initial dye concentration from $15 \mathrm{mg} / \mathrm{l}$ to $75 \mathrm{mg} / \mathrm{l}$, a decrease in percent adsorption from $95.4 \%$ to $72.19 \%$ was observed. Increase in adsorbent dosage (from $0.1 \mathrm{~g}$ to $0.5 \mathrm{~g}$ ), contact time (from $5 \mathrm{~min}$ to $40 \mathrm{~min}$ ) and pH from 2 to 10 resulted in increase in percent adsorption from $84.03 \%$ to $98.83 \%$, $54.24 \%$ to $84 \%$ and $48.17 \%$ to $84.03 \%$ respectively. About $98.83 \%$ removal of $\mathrm{MB}$ dye was achieved after $20 \mathrm{~min}$, at $\mathrm{pH}$ of 6 , temperature of $27 \pm 2{ }^{\circ} \mathrm{C}, 0.5 \mathrm{~g}$ weight of adsorbent and initial concentration of $60 \mathrm{mg} / \mathrm{l}$ of $50 \mathrm{ml} \mathrm{MB}$ dye solution. Langmuir isotherm best fits the equilibrium adsorption data with $\mathrm{R}^{2}=$ 0.996; the adsorption intensity obtained from Freundlich model ( $\mathrm{n}>1$ ) and the energy of adsorption obtained from the D-R model (< 8kJ/mol) suggested that physisorption dominates the adsorption of methylene blue onto the prepared activated carbon. Adsorption kinetic data was best described using Pseudo second order kinetic model $\left(\mathrm{R}^{2}=0.996\right)$, giving equilibrium rate constant $\left(\mathrm{k}_{2}\right)$ of $7690 \mathrm{~g} \mathrm{mg}^{-1} \mathrm{~min}^{-1}$. The characteristic results showed that bambaranut shell can be employed as an alternative to commercial adsorbents in the removal of methylene blue dye from aqueous solutions and waste water.

Keywords: Adsorption, Equilibrium isotherms, bambaranut shell biomass, methylene blue, activated carbon, adsorption kinetic models

\subsection{Introduction}

The increase in population and industrialization in Nigeria have lead to serious environmental pollution. Waste water from industries (such as food processing, textile, costmetics, plastics, etc) and man's activity (e.g. sewage, pesticides and fertilizers from agricultural run-off, etc) polluted with contaminants or toxic materials including dyes are discharged on land and into water bodies. These toxic materials are reported to have carcinogenic effects on living beings and severe cases can cause death $[1,2]$. There is need to maintain a clean environment for the survival of both plants and animals. This can be done by the treatment of waste water to remove the contaminants before discharge into the water or on land. Many conventional waste water treatment methods for the removal of contaminants include physiochemical, chemical and biological methods such as coagulation and flocculation, adsorption, ozonation, electrochemical techniques, fungal decolouration, ion exchange, chemical precipitation, reverse osmosis, etc. Research showed that adsorption is a very effective way of removing dyes from waste water because it is simple, cost effective and applicable at very low concentrations [3-7]. Adsorption is a surface phenomenon in which one or more components present in a multi-component fluid mixture is attracted to the surface of solid adsorbents through physical and chemical bonds. Organic and inorganic adsorbent materials have been used effectively in their raw, as well as modified forms for the removal of dyes from aqueous solutions with varying adsorption capacities $[2,8,9]$.

The use of agro-wastes as adsorbents for adsorption of dyes from waste water is advantageous, as it is a way of putting them to good use, converting the waste to wealth. Methylene blue dye $\left(\mathrm{C}_{16} \mathrm{H}_{18} \mathrm{~N}_{3} \mathrm{SCl}\right)$ is a basic aniline dye that forms a deep blue solution when dissolved in water. It is highly soluble in water and wet fast easily, hence, it is widely utilized in the industry for colouring paper, dyeing cotton, wool plastics and paperstocks, etc [5]. It is also used as a water tracer and biological stain. The permissible limit of methylene blue dye in the body is about $10 \mathrm{mg} / \mathrm{mL}$. The removal of methylene blue dye from waste water is important because its intake into the body of man and other animals above the permissible limit can accumulate within biological systems and cause cancer, it can also have other environmental damage [10]. Several studies on the adsorption of methylene blue on different adsorbents and adsorption of different contaminants on bambaranut shell have been reported in literature. Umoren et al., 2013 investigated the adsorption of methylene blue dye from waste water using unmodified poly(vinyl alcohol) [4]. The adsorption parameters were found to fit well into Langmuir, Freundlich and Temkin adsorption models, while kinetic studies showed that Pseudo-second order provided the best fit to the experimental data. Iliyasu et al., 2019 used carbonized unmodified Bambaranut shell and Delonixregia seed pods to remove methylene blue dye from waste water [11]. The study showed that the adsorbents are efficient in removal of methylene blue dye at pH 8 and 11 with $95.32 \%$ and $97.27 \%$ respectively. Ayuba and Nyijime 2019 investigated the adsorption of paraquat dichloride (PQ) from aqueous medium using carbonized unmodified bambaranut shell [12].

The kinetic and equilibrium studies showed that the adsorption process followed Pseudo-second order kinetics and Langmuir model. Jodeh et al., 2016 reported on the removal of methylene blue dye from industrial waste water using polysiloxane surface modified with bipyrazolic tripodal receptor [5]. The results obtained from the study revealed that over $80 \%$ removal efficiency of methylene blue dye was achieved in 180 minutes at solution around 10 . Other studies are those reported by Unal et al., 2013 (Removal of Methylene Blue from Aqueous Solution by Activated Carbon Prepared from Pea Shell), Manniru et al., 2015 (Adsorption Analysis of Congo Red Dye onto the Bambaranut Shell), Tatah et al., 2017 (Adsorption Isortherm and Kinetic Studies of Cd (II) and $\mathrm{Pb}$ (II) Ions Bioremediation from Aqueous Solution using Unmodified Bambara Groundnut Husk), Dargo et al., 2014 (Removal Of Methylene Blue Dye from Textile Waste Water using Activated Carbon Prepared from Rice-husk) $[7,13,14]$. However, the potentials of modified bambaranut shell on the adsorption of dyes from waste water were scantly reported in literature. The objective of this work is to investigate the potential and adsorption efficiency of modified adsorbent from local available bambaranut shell for the removal of methylene blue dye from aqueous solutions. The adsorbent was characterized to understand its morphology and porosity. The effects of operational parameters such as pH, amount of adsorbent (dosage), initial dye concentration and contact time on the adsorption of methylene blue onto bambaranut shell were reported. Langmuir, Freundlich, Temkin, Elovich, Redlich-Peterson, Dubinin- 
Radushkevich isotherm models were studied to understand the adsorption process. Kinetic studies were also evaluated using Pseudo-first order, Pseudosecond order, Elovich kinetic model and Intraparticle diffusion.<smiles>CN(C)c1ccc2nc3ccc(=[N+](C)C)cc-3sc2c1</smiles>

$\mathrm{Cl}^{-}$

Figure 1. Chemical structure of methylene blue

\subsection{Materials and methods}

\subsection{Materials}

Reagents: All chemicals are British Drug House (BDH) grade and were used without further purification. They are $10 \%$ phosphoric acid, $0.5 \mathrm{M} \mathrm{HCl}, 0.5 \mathrm{M}$ $\mathrm{NaOH}$, methylene blue (MB) dye (C16H18N3CIS). The stock solution of MB $(1000 \mathrm{mg} / \mathrm{l})$ was prepared by dissolving $1 \mathrm{~g}$ of solid MB in a $250 \mathrm{~cm}^{3}$ beaker, the resulting solution diluted to volume in a $1000 \mathrm{~cm}^{3}$ volumetric flask with distilled water. Apparatus used are beakers, measuring cylinders, electrical oven Model DHG 9023A, pH meter, Micrometrics model ASAP 2020, UV spectrophotometer Model 752, muffle furnance, Scanning Electron Microscope Phenom pro X, Electronic weighing balance model MB 2610 (sensibility reciprocal .0001g), rotary mechanical shaker, desiccator, grinder.

Preparation of the modified adsorbent: Bambaranut shells (BS) were collected from Abakpa market dumpsite in Abakaliki metropolis, Abakaliki Local Government Area of Ebonyi State, Nigeria. The BS were repeatedly washed with distilled water to remove dirts, dust and other impurities, and dried overnight in an oven at $80^{\circ} \mathrm{C}$ to reduce the moisture content. The dried BS was weighed and carbonized by heating at $400^{\circ} \mathrm{C}$ for $30 \mathrm{mins}$ in a muffle furnance. The resulting carbon was ground to fine particle size and subjected to activation. The carbonized BS was mixed with $100 \mathrm{ml}$ of phosphoric acid by stirring in a $500 \mathrm{ml}$ beaker for 4 hours. After activation/ modification, the mixture was diluted with deionized water and decanted several times, and then washed with double distilled water until the $\mathrm{pH}$ was tested to be 6 using a pH meter. The modified adsorbent was dried in an oven at a temperature of $105^{\circ} \mathrm{C}$ for 6 hrs and kept in an air tight container for further analysis.

\subsection{Methods}

\subsubsection{Characterization of the modified adsorbent}

The phosphoric acid modified bambaranut shell (PMBS) was characterized using the methods described [15,16].

Determination of bulk density: A portion (20g) of the PMBS was carefully transferred into a dry $100 \mathrm{ml}$ measuring cylinder, the cylinder was tapped for 5 mins to compact the carbon and the volume noted. Bulk density was calculated thus:

Bulk density $\left(\mathrm{g} /\left(\mathrm{cm}^{3}\right)=\frac{\text { mass of dry PMBS }(\mathrm{g})}{\text { volume of PMBS in the measuring cylinder }\left(\mathrm{cm}^{3}\right)}\right.$

Determination of moisture content: Thermal drying method was used in the determination of moisture content of the sample. A portion (2g) of dry PMBS was carefully measured into a pre-weighed beaker $\left(w_{1}\right)$ and the weight of the beaker and sample was noted $\left(w_{2}\right)$. The PMBS was carefully transferred to a laboratory oven set at $105^{\circ} \mathrm{C}$ and allowed to stand for $2 \mathrm{hrs}$. The PMBS was transferred to a dessicator and allowed to cool. The final weight ( $\mathrm{w}_{3}$ ) was noted.

Moisture content $(\%)=\frac{\mathrm{w}_{2}-\mathrm{w}_{3}}{\mathrm{w}_{2}-\mathrm{w}_{1}} \times 100$ or $\frac{\text { loss in weight on drying }(\mathrm{g})}{\text { initial weight of the PMBS }(\mathrm{g})} \times 100$

Determination of ash content: $A$ beaker is weighed $\mathrm{w}_{1}$, and $2.0 \mathrm{~g} \mathrm{w}$ of dry PMBS was measured into it. The beaker and its content was placed in a furnace and heated at $590^{\circ} \mathrm{C}$ for 3 hours. The beaker and its content was put in a desicator to cool and then weighed $\mathrm{w}_{3}$. The ash content was calculated using

Ash content $(\%)=\frac{\mathrm{w}_{3}-\mathrm{w}_{1}}{\mathrm{w}_{2}-\mathrm{w}_{1}} \times 100$ or $\frac{\text { ash weight }}{\text { oven dry weight }} \times 100$

Determination of pore volume: The BET surface area and pore volume of the PMBS was determined using a Micrometrics model ASAP 2020, 700VA made in USA. The average pore volume was calculated using the relationship:

Average pore volume $=4 x \frac{\text { total pore volume }}{\text { BET surface area }}$

Carbon yield determination: The weight of the carbon produced was weighed using an electrical weighing balance. The carbon yield was calculated using the equation:

Carbon yield $(\%)=\frac{\text { weight of carbon produced }}{\text { weight of sample used for carbonization }} \times 100$

SEM analysis: SEM was used to observe the physical morphology of the PMBS. The SEM analysis was carried out using Phenom pro X Scanning Electron Microscope, at a voltage of $10 \mathrm{kV}$, and magnifications of $200 \mu \mathrm{m}, 100 \mu \mathrm{m}, 80 \mu \mathrm{m}$.

\subsubsection{Effect of operational parameters}

Effect of $\mathbf{~ p H}$ of the methylene blue solution on its removal by the adsorbent: The adsorbent (PMBS), 0.1g was measured into five different beakers. $50 \mathrm{ml}$ of the dye solution of initial concentration of $60 \mathrm{mg} / \mathrm{l}$ and varying $\mathrm{pH}$ of 2, 4, 6, 8, 10 were transferred into the separate beakers. The pH of the solution 
was adjusted by means of $0.5 \mathrm{M} \mathrm{HCl}$ and $0.5 \mathrm{M} \mathrm{NaOH}$ solutions. The mixtures were agitated for 20 minutes in a Rotary mechanical shaker at $100 \mathrm{rpm}$ and at a temperature of $27 \pm 2{ }^{\circ} \mathrm{C}$. The solutions were filtered at equilibrium using a Whatman No. 1 filter paper and the filtrate analyzed for the residual dye using the UV spectrophotometer Model 752 at $620 \mathrm{~nm}$.

Effect of contact time on adsorption of methylene blue unto the adsorbent: The $0.1 \mathrm{~g}$ of the adsorbent (PMBS) was transferred into $50 \mathrm{ml}$ of $60 \mathrm{mg} / \mathrm{l}$ methylene blue (MB) solution. The mixtures were agitated for 5 minutes using a shaker and the content was filtered using a Whatman No. 1 filter paper. The filtrate was analyzed for the residual dye concentration using UV spectrophotometer. This was repeated for 10, 20, 30, and $40 \mathrm{minutes,} \mathrm{and} \mathrm{the} \mathrm{pH}$ of the solution was maintained at 6.

Effect of adsorbent dosage on adsorption of methylene blue: Different dosages of the activated carbon $(0.1 \mathrm{~g}, 0.2 \mathrm{~g}, 0.3 \mathrm{~g}, 0.4 \mathrm{~g}, 0.5 \mathrm{~g})$ were transferred into separate flasks after which $50 \mathrm{ml}$ of $60 \mathrm{mg} / \mathrm{l} \mathrm{MB}$ was added. The mixtures were agitated for $20 \mathrm{mins}$ in a shaker. The mixtures were filtered and the filtrates were analyzed for residual dye concentration using UV spectrophotometer.

Effect of increase in initial concentration of methylene blue on its adsorption unto the adsorbent: Different concentrations of MB solution (15, 30, $45,60,75 \mathrm{mg} / \mathrm{l}$ ) were prepared and poured into separate beakers containing $0.1 \mathrm{~g}$ of activated carbon. The mixtures were agitated for $20 \mathrm{mins}$ in a shaker. Then, the mixtures were filtered and the filtrates were analyzed using the UV spectrophotometer. The pH was maintained at 6.

The percentage adsorption of dye was calculated as follows:

$\%$ Dye adsorption $=\frac{c_{i}-c_{e}}{c_{i}} \times 100$

\subsubsection{Adsorption experiments}

Adsorption experiments were performed by the batch method to obtain adsorption data. The adsorption isotherm was investigated by adding $0.1 \mathrm{~g}$ of the PMBS to different concentrations of $50 \mathrm{ml}$ of the MB solution $(15,30,45,60,75 \mathrm{mg} / \mathrm{l})$ at $\mathrm{pH}$ of 6 . The mixtures were equilibrated for $20 \mathrm{mins}$ in a rotary mechanical shaker at 100rpm at room temperature. The solutions were filtered at equilibrium using a Whatman No. 1 filter paper. The filterate was analysed for the residual dye concentration using UV spectrophotometer Model 752 at $620 \mathrm{~nm}$. The amount of dye adsorbed at equilibrium $\mathrm{q}_{\mathrm{e}}$ was calculated using:

$\mathrm{q}_{\mathrm{e}}(\mathrm{mg} / \mathrm{g})=\frac{\left(\mathrm{c}_{\mathrm{i}}-\mathrm{c}_{\mathrm{e}}\right) \mathrm{v}}{\mathrm{w}}$

where $c_{i}$ and $c_{e}$ are the initial and final (equilibrium) concentration of dye $(\mathrm{mg} / \mathrm{l})$ respectively, $\mathrm{V}$ is the volume of the solution in (L), $w$ is the weight of the adsorbent used (g). To measure the adsorption kinetics, $60 \mathrm{mg} / \mathrm{l}$ of $50 \mathrm{ml}$ solution of MB and $0.1 \mathrm{~g}$ of the adsorbent was used and the contact time varied (5, 10, 20, 30, 40 mins). The $\mathrm{pH}$ was maintained at 6 . The amount of dye adsorbed at time $\mathrm{t}$, qt ( $\mathrm{mg} / \mathrm{g}$ ) was calculated by:

$\mathrm{q}_{\mathrm{t}}(\mathrm{mg} / \mathrm{g})=\frac{\left(\mathrm{c}_{\mathrm{i}}-\mathrm{c}_{\mathrm{t}}\right) \mathrm{v}}{\mathrm{w}}$

3.0. Results and discussion

3.1. Characterization of the PMBS

Table 1. Properties of the PMBS

\begin{tabular}{ll}
\hline Parameters & Values \\
\hline $\mathrm{pH}$ & 6 \\
Bulk density $\left(\mathrm{g} / \mathrm{cm}^{3}\right)$ & 0.303 \\
Carbon yield $(\%)$ & 59.24 \\
Moisture content $(\%)$ & 7.28 \\
Ash content $(\%)$ & 2.87 \\
Pore volume $\left(\mathrm{cm}^{3} / \mathrm{g}\right)$ & 0.530 \\
BET surface area $\left(\mathrm{m}^{2} / \mathrm{g}\right)$ & 193 \\
Average pore volume $(\mathrm{nm})$ & 10.98 \\
\hline
\end{tabular}

From table 1, the BET surface area and bulk density of the PMBS were high. Higher bulk density and surface area provide greater volume activity as it creates more active sites for adsorption to take place. The carbon yield was high and this shows that BS is a suitable precursor for the production of modified carbon. Similar values have been reported; $60.50 \%$ for commercially available modified carbon, $40.40 \%$ to $46.21 \%$ for coconut shell, bone carbon and wood carbon activated carbon, and less than that reported by Lafi et al., 2018, 18.7\% for coffee waste activated carbon [17,18]. The pore volume determines the rate at which the activated carbon can adsorb liquids; adsorption rate increases with increase in pore volume. The moisture content and ash content were low. Ash reduces the overall activity of activation carbon and the efficiency of reactivation. The low ash content of the PMBS signifies better adsorption properties.

\subsubsection{SEM analysis of the BSAC}
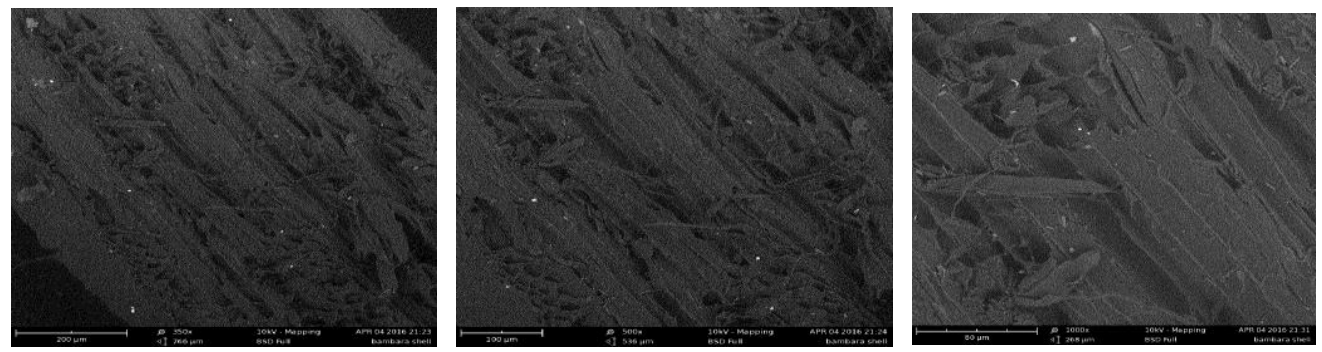
Figure 1. SEM micrographs of the PMBS at different magnifications

The SEM study carried out to know the physical morphology of the PMBS showed that the surface of the PMBS is rough and porous as can be seen in the SEM images in Fig 1. This means that the PMBS has good characteristics and can be used as an adsorbent for adsorption processes.

\subsection{The effect of operational parameters}

\subsubsection{The effect of $\mathrm{pH}$}

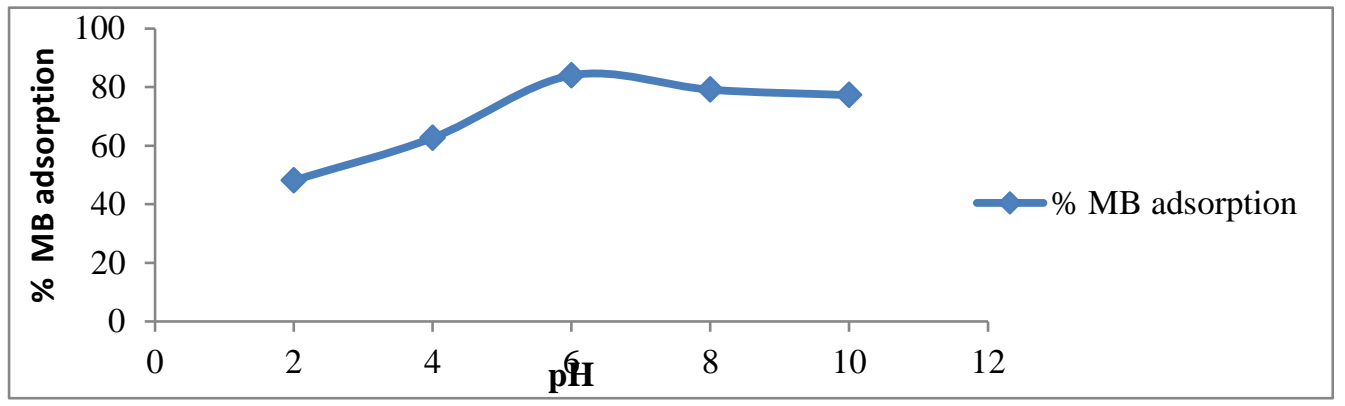

Figure 2. Effect of $\mathrm{pH}$ of the MB dye solution on its adsorption by PMBS

Initial concentration of $\mathrm{MB}$ solution $=60 \mathrm{mg} / \mathrm{l}$, adsorbent dose $=0.1 \mathrm{~g}$, contact time $=20 \mathrm{~min}$, agitation speed $=100 \mathrm{rpm}$ and $\mathrm{T}=27 \pm 2^{\circ} \mathrm{C}$

The $\mathrm{pH}$ of the methylene blue dye has effect on its adsorption by the modified carbon as shown in Fig 2 . The percentage adsorption of the dye increased from $48.17 \%$ to $84.03 \%$ with increase in $\mathrm{pH}$ from 2 to 6 . Beyond the $\mathrm{pH} 6$, the $\%$ adsorption of the dye decreased. The $\mathrm{pH} 6 \mathrm{was}$ the optimum $\mathrm{pH}$ and was selected for adsorption experiments. MB is a dipolar molecule which exists in anionic form at basic $\mathrm{pH}$ and as cationic form at acidic $\mathrm{pH}$. At low $\mathrm{pH}$, less number of cationic dye molecules is available compared to the number of hydrogen ion from the acidic solution. The hydrogen ions do not compete with the positively charged dye molecules and there is no inhibition to the adsorption process. As the $\mathrm{pH}$ of the system increases, the number of negatively charged site increases, and the number of positively charged site decreases. At higher $\mathrm{pH}$, more hydroxide ions are available and they compete with anionic dye molecules which are more in number than at low $\mathrm{pH}$ for adsorption sites. This reduces the percent adsorption of the MB solution, causing a decrease in adsorption [7,8,11,19]. Manniru et al., 2015 reported a similar trend and stated that it is due to the neutralization of the charges at the surface of the adsorbents [13]. This finding shows that toxic contaminants such as methylene blue dye can be removed by carbonized maodified bambaranut shell through adsorption at pH 6. Similar result obtained from literature is an optimum pH of 8 reported by Iliyasu et al., 2019 for methylene blue on unmodified bambaranut shell [11].

\subsubsection{Effect of contact time}

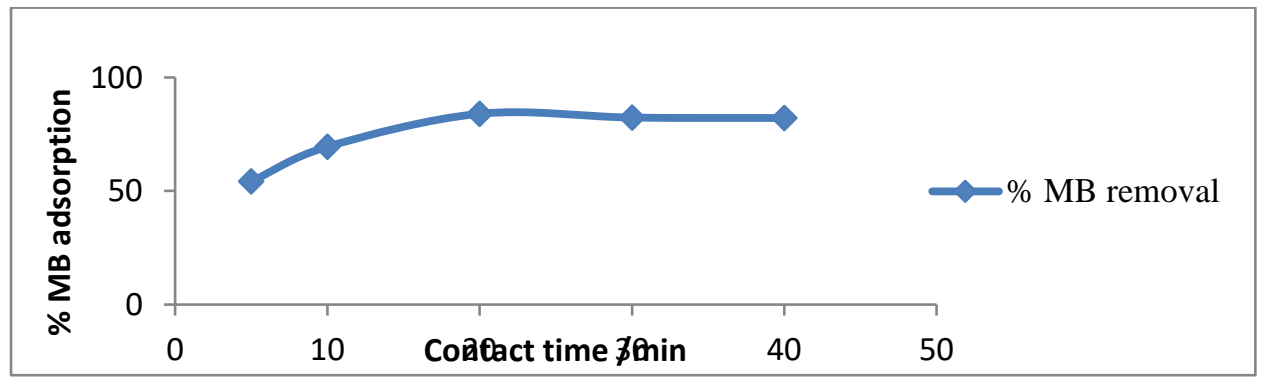

Figure 3. Effect of contact time on the adsorption of MB solution by PMBS

Initial concentration of $\mathrm{MB}$ solution $=60 \mathrm{mg} / \mathrm{l}$, adsorbent dose $=0.1 \mathrm{~g}$ per $50 \mathrm{ml}$ of solution, $\mathrm{pH}=6$, agitation speed $=100 \mathrm{rpm}$ and $\mathrm{T}=27 \pm 2{ }^{\circ} \mathrm{C}$

The percentage adsorption of MB gradually increased from $54.24 \%$ to $84 \%$ with increase in contact time up to a certain point ( 5 min to $20 \mathrm{~min}$ ), and then a constant in \% adsorption as shown in Fig 3, and can be due to large available active sites on the adsorbent surface for adsorption. At equilibrium, the active sites are saturated and the rate of adsorption becomes constant or decreases. Based on these results, 20 min was taken as the equilibrium time in the batch adsorption experiments. Similar trends were reported [11, 20-22]. Iliyasu et al., 2019 obtained about $42 \%$ removal of methylene blue after 400 min for unmodified BS. This proved that modified carbon is more effective for adsorption than unmodified carbon.

\subsubsection{Effect of adsorbent dosage}

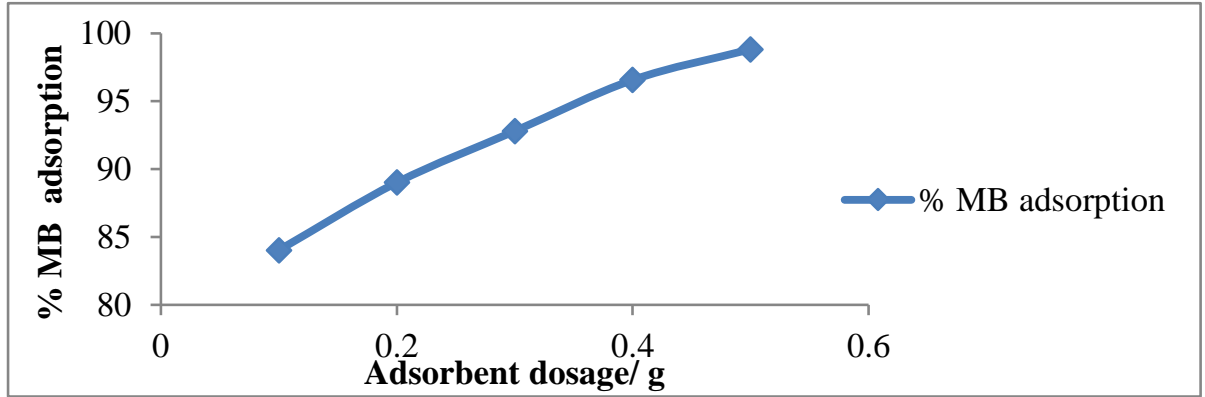


Figure 4. Effect of adsorbent dosage on the adsorption of $\mathrm{MB}$

Initial concentration of $\mathrm{MB}$ solution $=60 \mathrm{mg} / \mathrm{l}$, contact time $=20 \mathrm{~min}$, agitation speed $=100 \mathrm{rpm}, \mathrm{pH}=6$ and $\mathrm{T}=27 \pm 2^{\circ} \mathrm{C}$

As shown in Fig 4, there was increase in percentage adsorption from $84.03 \%$ to $98.83 \%$ as the dosage of the PMBS increased from $0.1 \mathrm{~g}$ to $0.5 \mathrm{~g}$. Increase in surface area and active centers with increasing adsorbent dosage may have led to increase in percentage adsorption [2,5, 23,24,].

3.2.4. Effect of increase in initial concentration of methylene blue

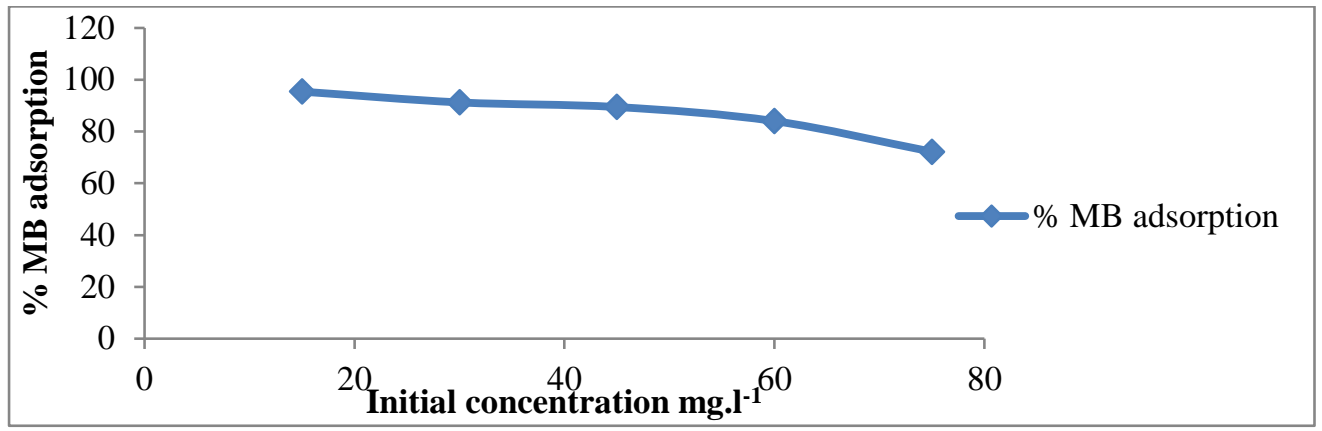

Figure 5. Effect of initial concentration of dye on adsorption of MB

Adsorbent dose $=0.1 \mathrm{~g}$ per $50 \mathrm{ml}$ of solution, contact time $=20 \mathrm{~min}$, agitation speed $=100 \mathrm{rpm}, \mathrm{pH}=6$ and $\mathrm{T}=27 \pm 2^{\circ} \mathrm{C}$

Fig 5 shows the effect of initial concentration of dye on the adsorption of MB by the BSAC. The percent adsorption decreased from $95.40 \%$ to $72.19 \%$ as the initial MB concentration increases from $15 \mathrm{mg} / \mathrm{l}$ to $75 \mathrm{mg} / \mathrm{l}$. This may be due to high ratio of surface active sites to the dye molecule in solution at low concentration which enables the dye molecules to interact with the activated carbon effectively. At high concentration, the active sites becomes saturated and adsorption rate decreases $[4,14,20]$.

\subsection{Equilibrium studies}

The equilibrium studies indicate how the adsorption molecules are distributed between the liquid phase when the adsorption process reaches an equilibrium state [2]. It provides the fundamental information on the adsorption mechanism, surface properties and the affinity of adsorbents, which helps to determine the application of adsorption as a unit operation [7]. The results obtained on the adsorption of MB onto PMBS were tested by different isotherm models as follows.

\subsubsection{Langmuir model}

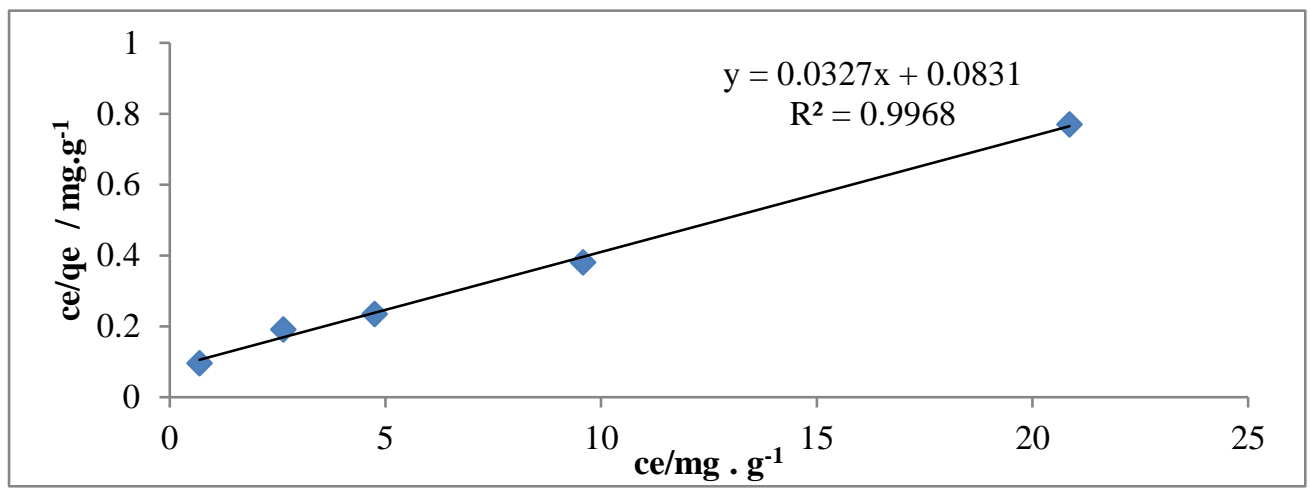

Figure 6. Langmuir isotherm plot for MB adsorption onto PMBS

This model assumes that the adsorption occur at specific homogenous active sites on the adsorbent (Unal et al., 2013). The linear form of Langmuir equation is expressed as $[2,7,24]$ :

$\frac{c_{e}}{q_{e}}=\frac{c_{e}}{q_{m}}+\frac{1}{q_{m} K_{L}}$

where $\mathrm{q}_{\mathrm{e}}$ is the amount of dye adsorbed at equilibrium $(\mathrm{mg} / \mathrm{g})$, $\underline{\mathrm{c}}_{\mathrm{e}}$ is the equilibrium concentration of the adsorbate $(\mathrm{mg} / \mathrm{L}), \mathrm{q}_{\mathrm{m}}$ and $\mathrm{KL}$ are Langmuir constants related to the maximum adsorption capacity in $(\mathrm{mg} / \mathrm{g})$ and energy of adsorption $(\mathrm{L} / \mathrm{mg})$, and can be calculated from the linear graphical plot of $\underline{c_{e}} / q_{\mathrm{e}}$ against $\mathrm{c}_{\mathrm{e}}$. The slope of the graph corresponds to $1 / \mathrm{q}_{\mathrm{m}}$, while the intercept is $1 / \mathrm{q}_{\mathrm{m}} \mathrm{K}_{\mathrm{L}}$. The graphical plot of $\underline{\mathrm{c}}_{\mathrm{e}} / \mathrm{q}_{\mathrm{e}}$ against $\mathrm{c}_{\mathrm{e}}$ gives a straight line graph as shown in Fig 6. The Langmuir constants $\mathrm{K}_{\mathrm{L}}$ and maximum adsorption capacity $\mathrm{q}_{\mathrm{m}}$ calculated from the intercept and slope of the plots respectively are $0.385 \mathrm{~L} / \mathrm{mg}$ and $31.25 \mathrm{mg} / \mathrm{g}$. The correlation coefficient $\mathrm{R}^{2}$ is 0.996 , and indicates that the adsorption follows Langmuir isotherm closely. The dimensionless separation factor $R_{L}$ which is a measure of the desirability and favourability of the model was found to be 0.04 , indicating high favourability of the adsorption of MB onto PMBS. $R_{L}$ predicts the affinity between the adsorbate and the adsorbent. Adsorption is favourable if $0<R_{L}<1$, unfavourable if $R_{L}>1$, linear if $\mathrm{R}_{\mathrm{L}}=1$ or irreversible if $\mathrm{R}_{\mathrm{L}}=0$. $\mathrm{R}_{\mathrm{L}}$ is calculated using

$R_{L}=\frac{1}{1+K_{L} c_{o}}$ 
The Langmuir parameters are presented in Table 2.

\subsubsection{Freundlich Isotherm}

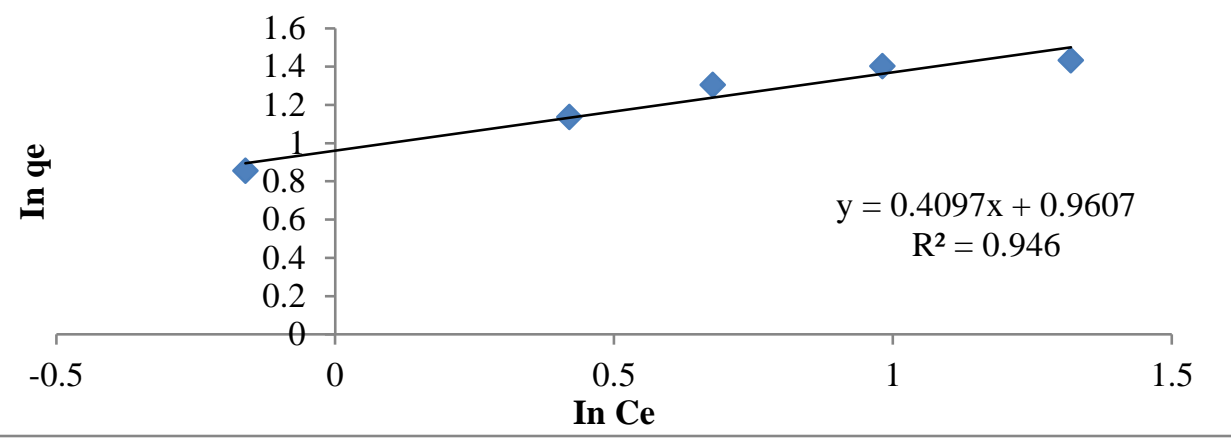

Figure 7. Freundlich isotherm plot for MB adsorption onto PMBS

This model assumes that adsorption takes place on a heterogenous adsorbent surface, where the sorption energy distribution decreases exponentially [7]. The linearized Freundlich equation is $[6,7,26,27]$ :

$\log q_{e}=\log K_{f}+\frac{1}{n} \log c_{e}$

where $\mathrm{q}_{\mathrm{e}}$ is the amount of dye adsorbed at equilibrium $(\mathrm{mg} / \mathrm{g}), \mathrm{c}_{\mathrm{e}}$ is the equilibrium concentration of the adsorbate (mg/L), $\mathrm{K}_{\mathrm{f}}$ is the adsorption capacity of the adsorbate (L/g), $\mathrm{n}$ is the adsorption intensity $(\mathrm{g} / \mathrm{L})$. The plot of $\log \mathrm{q}_{\mathrm{e}}$ against $\log \mathrm{c}_{\mathrm{e}}$ in Fig 7 gives a straight-line graph of slope $1 / \mathrm{n}$ and intercept $\log \mathrm{K}_{\mathrm{f}}$. From Table 2, the value of slope $1 / \mathrm{n}$ (which is a measure of adsorption intensity or surface heterogeneity) is 0.409 (between 0 and 1 ), while $\mathrm{n}$ is 2.44 (ranges from 1 to 10), indicating that the adsorption of MB dye unto PMBS is by physical process [5,6]. If $n=1$, adsorption is linear, if $n>1$, adsorption is a physical process, if $\mathrm{n}<1$, adsorption is a chemical process $[26,28]$. The $\mathrm{R}^{2}$ is 0.946 , this value is lower than the $\mathrm{R}^{2}$ for Langmuir $(0.996)$ and Temkin isotherm (0.968). $\mathrm{K}_{\mathrm{f}}$ is $9.120 \mathrm{~L} / \mathrm{g}$ and it shows high adsorption capacity. The larger the value of $\mathrm{K}_{\mathrm{f}}$, the higher is the adsorption capacity [6]. Table 2 shows that Freundlich model could also be used to explain the adsorption process.

\subsubsection{Temkin isotherm}

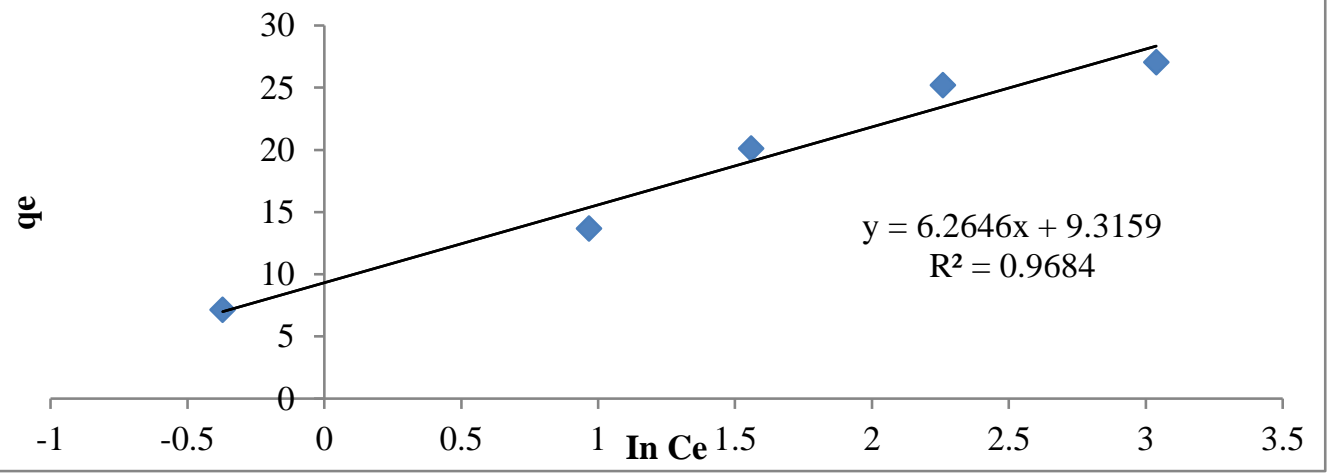

Figure 8. Temkin isotherm plot for MB adsorption onto PMBS

This takes into account the effects of indirect adsorbent/adsorbate interactions on the adsorption process. It assumes that the heat of adsorption $\beta$ of all molecules in the layer decreases linearly as a result of increased surface coverage due to the adsorbent or adsorbate interaction $[8,24,29]$. The linear form of Temkin isotherm model is given as:

$q_{e}=\beta_{T} \operatorname{In} A_{T}+\beta_{T} \operatorname{Inc} c_{e}$

where $\beta_{T}=\frac{R T}{b_{T}}, \mathrm{~b}_{\mathrm{T}}$ is the Temkin constant related to heat of sorption $(\mathrm{J} / \mathrm{mol}), \mathrm{A}_{\mathrm{T}}$ is the Temkin isotherm constant $(\mathrm{L} / \mathrm{g}), \mathrm{R}$ is the universal gas constant $(8.314 \mathrm{~J} / \mathrm{mol} \mathrm{K})$, T absolute temperature (K). By plotting $\mathrm{q}_{\mathrm{e}}$ against $\mathrm{In} \mathrm{C}_{\mathrm{e}}$ as shown in Fig 8, the constants $\mathrm{b}_{\mathrm{T}}$ and $\mathrm{A}_{\mathrm{T}}$ can be calculated from the slope and intercept. The graphically calculated $\mathrm{b}_{\mathrm{T}}, \mathrm{B}_{\mathrm{T}}$ and $\mathrm{A}_{\mathrm{T}}$ were $0.398 \mathrm{~kJ} / \mathrm{mol}, 6.264 \mathrm{~kJ} / \mathrm{mol}$ and $4.42 \mathrm{~L} / \mathrm{g}$ respectively, and are presented in Table 2 . The magnitude of $\mathrm{b}_{\mathrm{T}}$ was low and shows that the process might be physical adsorption [8]. The $\mathrm{R}^{2}$ is 0.968 , and indicates a good fit for the adsorption process.

\subsubsection{Elovich isotherm}




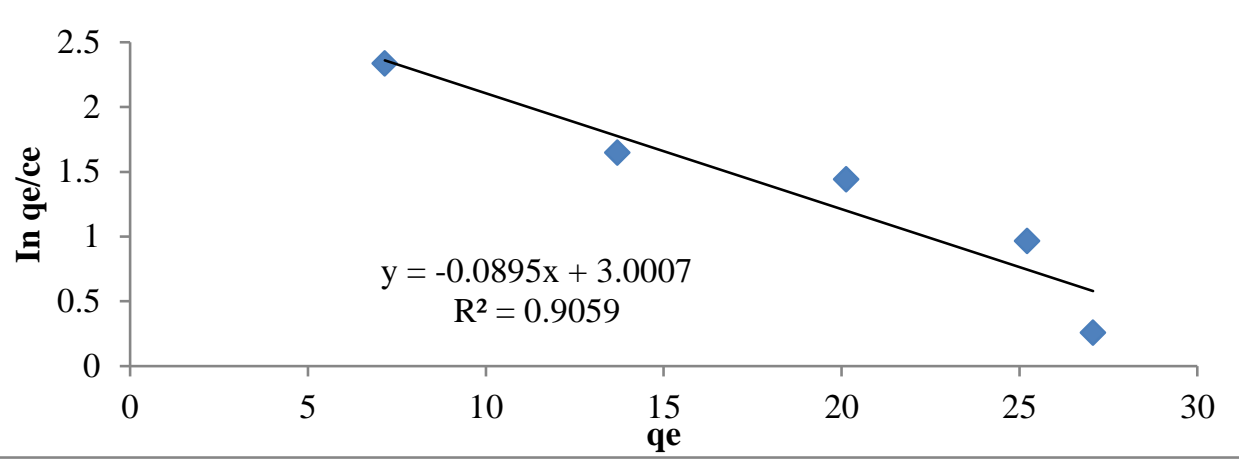

Figure 9. Elovich isotherm plot for MB adsorption onto PMBS

This model assumes that the adsorption site grows exponentially with adsorption, indicating multilayer adsorption. This model is often valid for systems in which the adsorbing surface is heterogenous $[6,24,29,30]$. The linear form of Elovich isotherm is expressed as:

$$
\frac{\operatorname{Inc} c_{e}}{c_{e}}=\operatorname{In} k_{e} q_{m}-\frac{q_{e}}{q_{m}}
$$

where $\mathrm{q}_{\mathrm{m}}=$ Elovich maximum adsorption capacity, $\mathrm{k}_{\mathrm{e}}=$ Elovich constant

The plot of $\mathrm{In} \mathrm{q}_{\mathrm{e}} / \mathrm{c}_{\mathrm{e}}$ against $\mathrm{q}_{\mathrm{e}}$ shows a poor fit as $\mathrm{R}^{2}$ value is 0.905 . The values of $\mathrm{q}_{\mathrm{m}}$ and $\mathrm{k}_{\mathrm{e}}$ calculated from the slope and intercept of the plot are 12.35 and 1.216 respectively. The low value of $\mathrm{q}_{\mathrm{m}}$ shows that the adsorbing surface is homogenous as stipulated by the Langmuir model $[24,30,31]$.

\subsubsection{Dubinin- Radushkevich (D-R) isotherm}

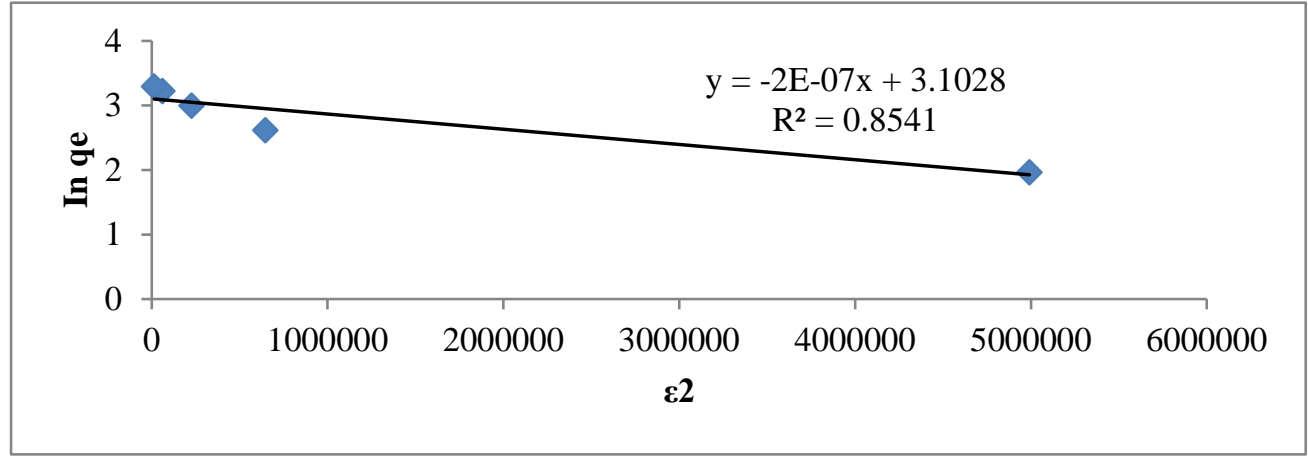

Figure 10. D-R isotherm plot for MB adsorption onto PMBS

This model estimates the characteristic porosity and apparent free energy of adsorption. It helps to determine the nature of adsorption processes, whether physical or chemical. The linear form of D-R isotherm is [7,8,25]:

$\operatorname{In} q_{e}=\operatorname{In} q_{m}-\beta \varepsilon^{2}$

where $\mathrm{q}_{\mathrm{m}}$ is the theoretical saturation capacity $(\mathrm{mg} / \mathrm{g}), \beta$ is a co-efficient related to the mean free energy of adsorption $\left(\mathrm{mol}^{2} / \mathrm{J}^{2}\right), \varepsilon$ is the Polanyi potential expressed as $\varepsilon=$ RT In $1+\frac{1}{c_{\mathrm{e}}}$. The mean free energy $\mathrm{E}$ of the adsorption per molecule of adsorbate can be calculated using the equation $E=\frac{1}{2 \beta^{0.5}}$. The mean free energy gives information about chemical or physical adsorption. With the value of $\mathrm{E}>8 \mathrm{~kJ} / \mathrm{mol}$, the sorption process follows chemical ionexchange, while with the value of $\mathrm{E}<8 \mathrm{~kJ} / \mathrm{mol}$, the sorption is of physical nature [7,8,25]. A plot of $\mathrm{In} \mathrm{q}_{\mathrm{e}}$ against $\varepsilon^{2}$ provided a poor fit to the experimental data, as indicated by the $\mathrm{R}^{2}$ value 0.854 . This is shown on Table 2 and Fig 10 . The constants $\beta$ and $\mathrm{q}_{\mathrm{m}}$ were calculated from the slope and intercept respectively as $2 \times 10^{-7}\left(\mathrm{~mol}^{2} / \mathrm{J}^{2}\right)$ and $22.24 \mathrm{mg} / \mathrm{g}$. The value of the apparent energy E $(1.581 \mathrm{~kJ} / \mathrm{mol})$ of the MB as shown in Table 2 is below $8 \mathrm{~kJ} / \mathrm{mol}$, this shows that the adsorption was largely due to physisorption mechanism as suggested by Temkin isotherm. Similar results have been reported by many researchers $[7,8,25,32-34]$.

Table 2. Equilibrium constants for the adsorption of MB onto BSAC

\begin{tabular}{lllll}
\hline Equilibrium models & Constants & & & \\
\hline Langmuir & $\mathrm{q}_{\mathrm{m}}$ & $31.25 \mathrm{mg} / \mathrm{g}$ & $\mathrm{R}_{\mathrm{L}}$ & 0.04 \\
& $\mathrm{~K}_{\mathrm{L}}$ & $0.385 \mathrm{~L} / \mathrm{mg}$ & $\mathrm{R}^{2}$ & 0.996 \\
Freundlich & $\mathrm{K}_{\mathrm{f}}$ & $9.120 \mathrm{~L} / \mathrm{g}$ & $\mathrm{n}$ & 2.44 \\
& $1 / \mathrm{n}$ & 0.409 & $\mathrm{R}^{2}$ & 0.946 \\
Temkin & $\mathrm{b}_{\mathrm{T}}$ & $0.398 \mathrm{~kJ} / \mathrm{mol}$ & $\mathrm{B}_{\mathrm{T}}$ & $6.264 \mathrm{~kJ} / \mathrm{mol}$ \\
& $\mathrm{A}_{\mathrm{T}}$ & $4.42 \mathrm{~L} / \mathrm{g}$ & $\mathrm{R}^{2}$ & 0.968 \\
Elovich & $\mathrm{q}_{\mathrm{m}}$ & 12.35 & $\mathrm{R}^{2}$ & 0.905 \\
& $\mathrm{k}_{\mathrm{e}}$ & 1.216 & & \\
D-R & $\mathrm{q}_{\mathrm{m}}$ & $22.24 \mathrm{mg} / \mathrm{g}$ & $\mathrm{E}$ & $1.581 \mathrm{~kJ} / \mathrm{mol}$ \\
& $\beta$ & $2 \times 10^{-7} \mathrm{~mol} / \mathrm{J}^{2}$ & $\mathrm{R}^{2}$ & 0.854 \\
\hline
\end{tabular}




\subsection{Adsorption kinetics}

Several kinetic models were applied to examine the mechanism of the adsorption of dye from aqueous solution. Pseudo first order, pseudo second order, Intra-particle diffusion and Elovich kinetic models were studied.

\subsubsection{Pseudo-first order}

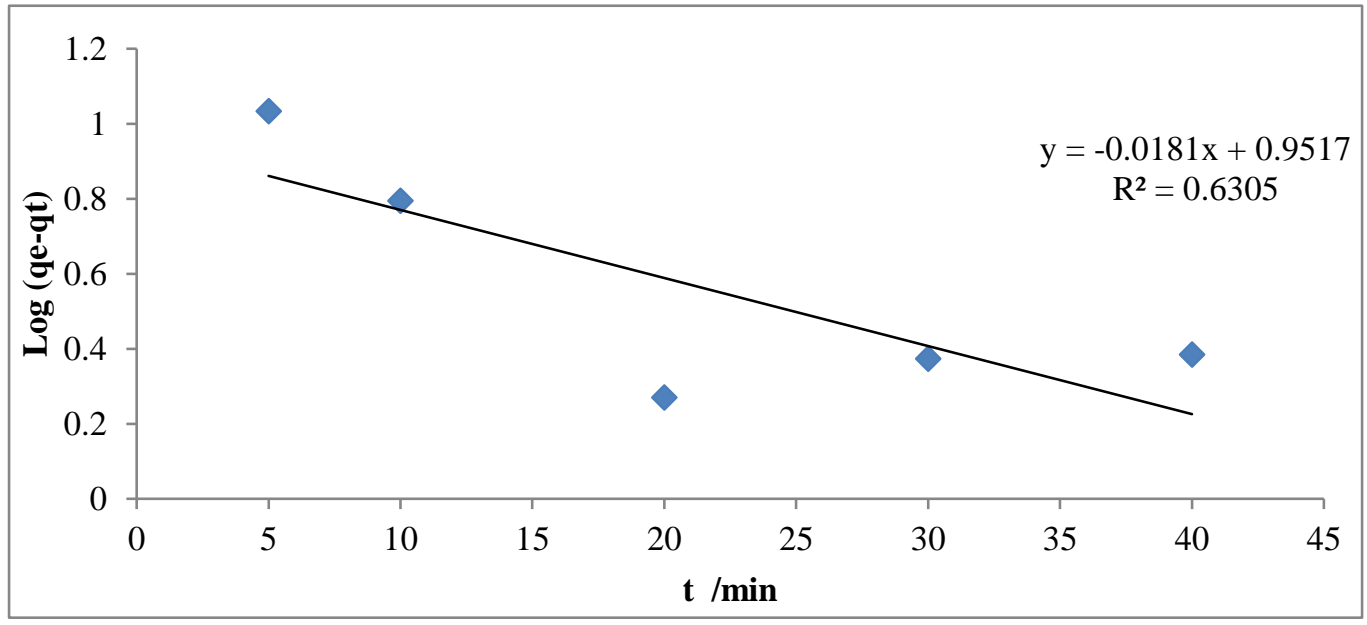

Figure 11. Pseudo -first order adsorption kinetics on MB

The linearized Pseudo-first order rate equation is expressed as

$\log \left(q_{e}-q_{t}\right)=\log q_{e}-\frac{k_{1}}{2.303} t$

where $\mathrm{q}_{\mathrm{e}}$ and $\mathrm{q}_{\mathrm{t}}$ are the amounts of $\mathrm{MB}$ adsorbed $(\mathrm{mg} / \mathrm{g})$ at equilibrium and at time $\mathrm{t}(\mathrm{min})$ respectively, $\mathrm{k} 1\left(\mathrm{~min}^{-1}\right)$ is the adsorption rate constant, $\mathrm{t}$ is the contact time (min). A plot of $\log (\mathrm{qe}-\mathrm{qt})$ against t shown in Fig 11 gives a linear graph, from which $\mathrm{k}_{1}\left(0.0414 \mathrm{~min}^{-1}\right)$ and $\mathrm{q}_{\mathrm{e}}(8.93 \mathrm{mg} / \mathrm{g}) \mathrm{are}$ determined from the slope and intercept respectively. The regression coefficient $\mathrm{R}^{2}$ is 0.630 and indicated poor fitness for the Pseudo-first order model. Results of nonfitting of Pseudo-first order kinetic to adsorption have been reported.

\subsubsection{Pseudo-second order}

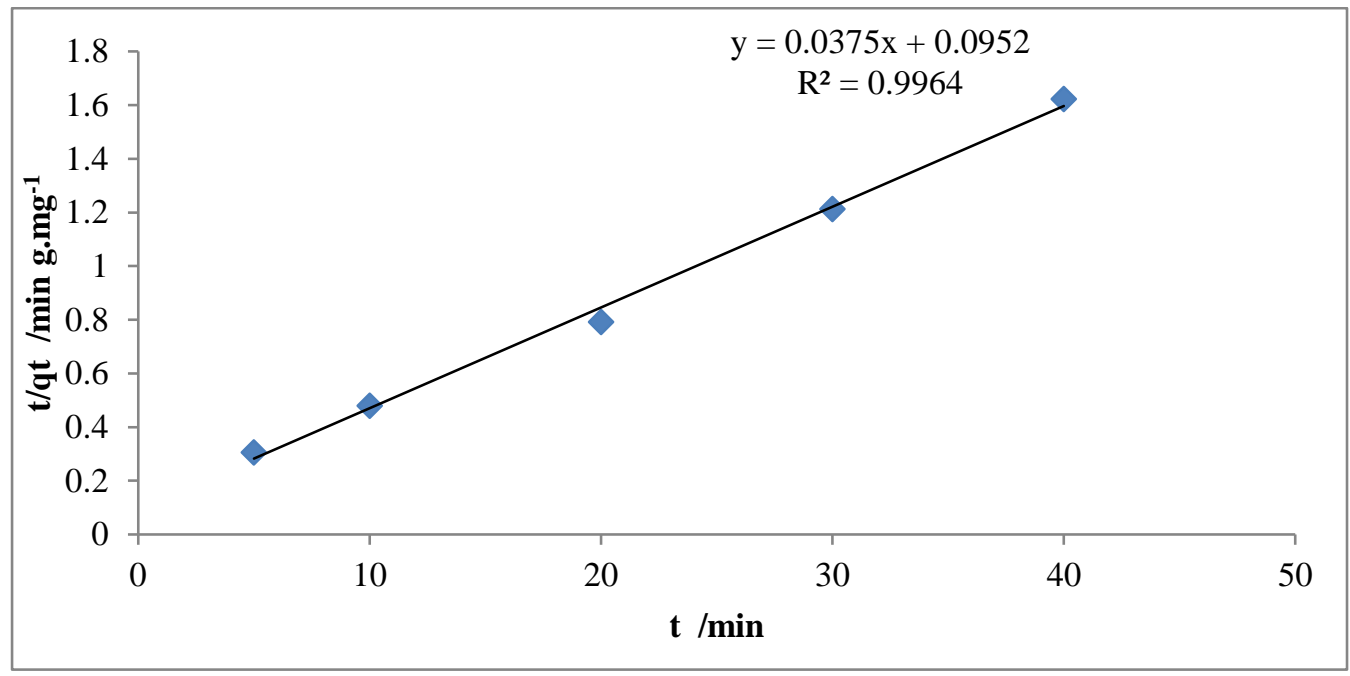

Figure 12. Pseudo-second order kinetic plot for the adsorption of MB onto BSAC

The linear form of pseudo - second order is given as

$$
\frac{t}{q_{t}}=\frac{1}{k_{2}} q_{e}^{2}+\frac{1}{q_{e}} t
$$

$\mathrm{k}_{2}$ is pseudo - second order constant (g/mg min). As shown in Fig 12 and Table 3, the plot of $\mathrm{t} / \mathrm{q}_{\mathrm{t}}$ against $\mathrm{t}$ gives $\mathrm{R}^{2}$ (0.996), indicating that the pseudosecond order equation fitted the experimental data well with a correlation close to unity. $\mathrm{k}_{2}(7690.75 \mathrm{~g} / \mathrm{mg} \mathrm{min})$ and $\mathrm{q}_{\mathrm{e}}(27.03 \mathrm{mg} / \mathrm{g}) \mathrm{were}$ calculated from the intercept and slope of the graph respectively. The $\mathrm{k}_{2}>\mathrm{k}_{1}$, hence, the pseudo-second order better represented the adsorption kinetics. Similar results have been reported $[2,4,5,8,24]$.

\subsubsection{Intra-particle diffusion model}




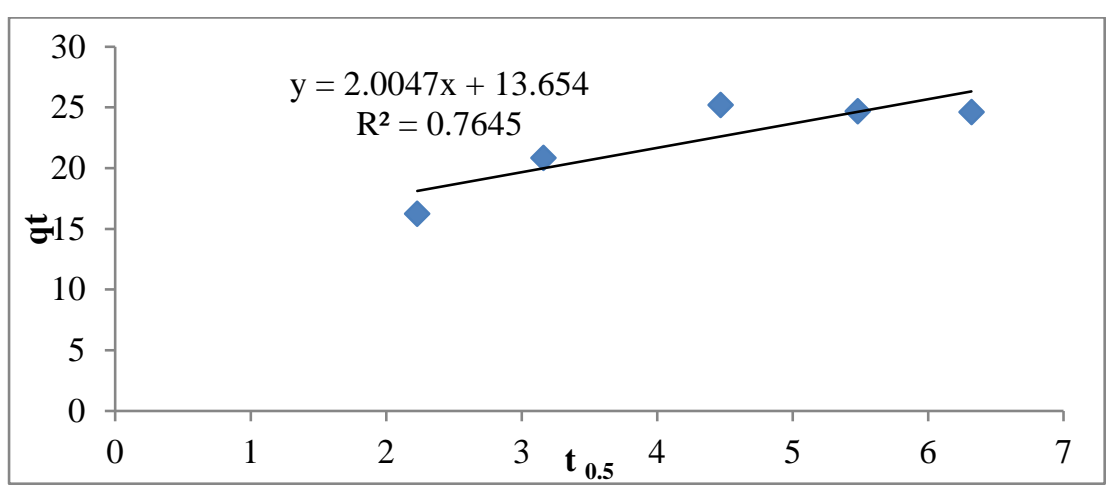

Figure 13. Intra-particle diffusion model kinetic plot for the adsorption of MB onto PMBS

The intra-particle diffusion model was applied to investigate the adsorption rate limiting step. The intra-particle diffusion model (IPDM) formula as given by Weber and Morris is

$q_{t}=k_{i d} t^{\frac{1}{2}}+C$

$\mathrm{k}_{\mathrm{id}}\left(\mathrm{mg} /\left(\mathrm{gmin}^{-1 / 2}\right)\right)$ is the rate constant for intra-particle diffusion (IPD). The intercept $\mathrm{C}$ in a plot of $\mathrm{q}_{\mathrm{t}}$ against $\mathrm{t}^{1 / 2}$ represents the thickness of the boundary layer. If $\mathrm{C}=0$, the IPD is the sole rate limiting step, and the larger the value of $\mathrm{C}$, the greater is the boundary layer effect $[7,21,23,25]$. Table 3 and Fig 12 showed the $\mathrm{k}_{\mathrm{id}}$ (2.004), $\mathrm{R}^{2}=0.763$, indicating that the adsorption of MB on PMBS cannot be described by IPDM. The value of C (13.65) shows that the line did not pass through the origin, $\mathrm{C} \neq 0$, implying that IPDM is not the sole rate limiting step, hence, there are some other processes affecting the adsorption $[9,25]$. The value of $\mathrm{C}$ may be due to differences in mass movement of adsorbate in the beginning and ending processes of the sorption, implicating boundary layer control in the adsorption $[7,24,35,36]$.

\subsubsection{Elovich kinetic model}

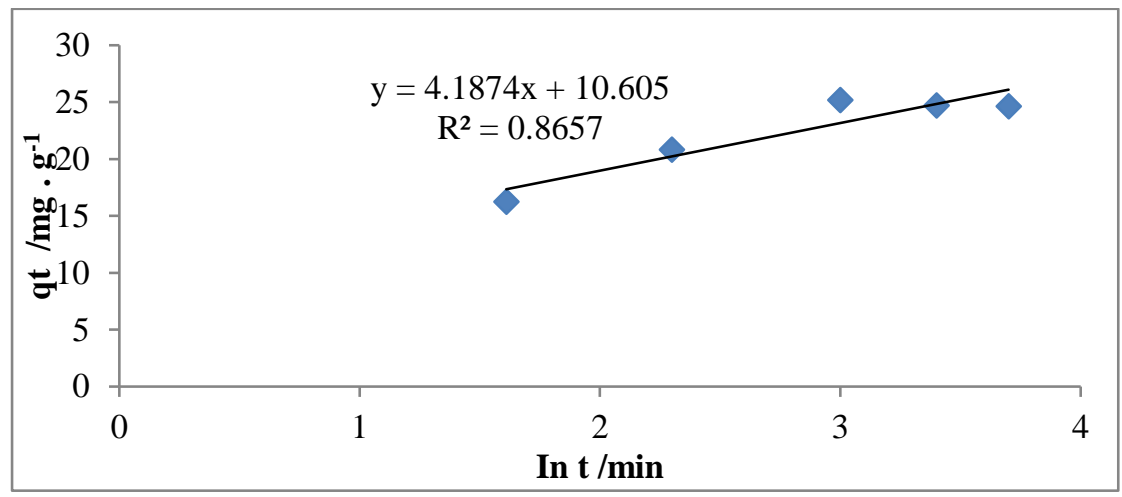

Figure 14. Elovich kinetic plot for the adsorption of MB on PMBS

This model describes the kinetics of chemisorptions of gas and or solute onto solid adsorbents and is expressed as $[8,21,24,37]$.

$q_{t}=\frac{1}{\beta} \operatorname{In}(\alpha \beta)+\frac{1}{\beta} \operatorname{In} t$

$\alpha$ is the initial adsorption rate ( $\mathrm{mg} / \mathrm{g} \mathrm{min})$ and $\beta$ is extent of surface coverage and activation energy for chemisorptions ( $\mathrm{g} \mathrm{mg}^{-1}$ ). The values of $\alpha(5.59 \mathrm{mg} / \mathrm{g}$ $\min )$ and $\beta\left(0.23 \mathrm{~g} \mathrm{mg}^{-1}\right)$ were calculated from the intercept and slope of the plot of $\mathrm{q}_{\mathrm{t}}$ against In t respectively shown in Fig 14. The higher value of $\alpha$ than $\beta$ indicated higher adsorption rate than chemisorptions, which showed viability of adsorption process [8]. The low value of $\mathrm{R}^{2}(0.865)$ showed poor fit for this model. Comparing the correlation co-efficients of pseudo-first, pseudo-second, intra-particle diffusion and Elovich models, one can say that the adsorption of MB onto PMBS was best represented by pseudo-second order.

Table 3. Comparism of kinetic parameters for the adsorption of MB onto BSAC

\begin{tabular}{lll}
\hline Kinetic models & Parameters & \\
\hline Pseudo-first order & $\mathrm{k}_{1}$ & $0.0414 \mathrm{~min}^{-1}$ \\
& $\mathrm{q}_{\mathrm{e}}$ & $8.93 \mathrm{mg} / \mathrm{g}$ \\
Pseudo-second order & $\mathrm{R}^{2}$ & 0.630 \\
& $\mathrm{k}_{2}$ & $7690 \mathrm{~g} / \mathrm{mg} \mathrm{min}$ \\
& $\mathrm{q}_{\mathrm{e}}$ & $27.03 \mathrm{mg} / \mathrm{g}$ \\
Intra-particle diffusion & $\mathrm{R}^{2}$ & 0.996 \\
& $\mathrm{k}$ & 2.006 \\
Elovich & $\mathrm{C}$ & 13.64 \\
& $\mathrm{R}^{2}$ & 0.763 \\
& $\alpha$ & $5.59 \mathrm{mg} / \mathrm{g} \min$ \\
\hline
\end{tabular}




\subsection{Conclusion}

Bambaranut shell modified adsorbent was prepared, characterized and used to investigate the adsorption of MB from aqueous solutions. SEM images of the adsorbent showed rough and porous surfaces, indicating that the adsorbent has good properties and can be used for adsorption processes. Results from the study of the effect of contact time, $\mathrm{pH}$, initial dye concentration and adsorbent dose on adsorption showed increase in percentage adsorption with increase in contact time from $5 \mathrm{~min}$ to $20 \mathrm{~min}$, and then a decline, increase in percentage adsorption with increase in $\mathrm{pH}$ (optimum adsorption was obtained at $\mathrm{pH}$ 6), decrease in percentage adsorption with increase in initial MB concentration , and increase in percentage adsorption with increase in the amount of adsorbent dosage. About $98.83 \%$ removal of $\mathrm{MB}$ dye was achieved after $20 \mathrm{~min}$, at $\mathrm{pH}$ of 6 , temperature of $27 \pm 2{ }^{\circ} \mathrm{C}$ and $0.5 \mathrm{~g}$ weight of adsorbent and initial concentration of $60 \mathrm{mg} / \mathrm{l}$ of $50 \mathrm{ml} \mathrm{MB}$ dye solution. The adsorption isotherm was well fitted by the Langmuir model with best fit. Judging from the $\mathrm{R}^{2}$ values, equilibrium adsorption data fit into isothermal models in this order: Langmuir $>$ Temkin $>$ Freundlich $>$ Elovich $>$ D-R. The adsorption intensity obtained from Freundlich model and the energy of adsorption obtained from the D-R model suggested that physisorption dominates the sorption of MB onto PMBS. The adsorption kinetics can be described using Pseudo second order. Based on the values $\mathrm{R}^{2}$, the trend in adsorption kinetics is Pseudo second order $>$ Elovich $>$ Intra-particle diffusion $>$ Pseudo first order.

\subsection{Acknowledgements}

The authors wish to acknowledge the efforts of Graceland Analytical Laboratory, Anambra State and Evangel University Akaeze, Ebonyi State, Nigeria, towards the success of this work.

\subsection{Declaration of conflict of interest}

The authors confirm that there was no known conflict of interest associated with this work, and there has been no significant financial support for this work that could have influenced its outcome.

\subsection{References}

[1] B. Acemioglu, "Adsorption of Congo Red from Aqueous Solution onto Calcium-rich Fly Ash", Journal of Colloid and Interface Science, Vol. 274, No. 2, Pp. 371-379, 2004.

[2] G. Unal, O. Gulce, and C.G. Gizem, "Removal of Methylene Blue from Aqueous Solution by Activated Carbon Prepared from Pea Shell (Pisum sativum)", Journal of Chemistry, Pp. 1-9, 2013. http://dx.doi.org/10.1155/2013/614083.

[3] R. Saadi, Z. Saadi, R. Fazaeli and E.N. Fard, “Monolayer and Multilayer Adsorption Isotherm Models for Sorption from Aqueous Media”, Korean Journal of Chemical Engineering, Vol. 35, No. 5, Pp. 787-799, 2015. DOI:10.1007/S1814-015-0053-7.

[4] S.A. Umoren, U.J. Etun, and A.U. Israel, "Adsorption of Methylene Blue from Industrial Effluent using Poly (Vinyl Alcohol)", Journal of Material and Environmental Science, Vol. 4, No. 1, Pp. 75-86, 2013.

[5] S. Jodeh, J. Amarah, S. Radi, O. Hamed, I. Warad, R. Salghi, A. Chetouni, S. Samhan, and R. Alkowin, "Removal of Methylene Blue from Industrial Wastewater in Palestine using Polysiloxane Surface Modified with Bipyrazolic Tripodal Receptor”, Morocean Journal of Chemistry, Vol. 4, No. 1, Pp. 140-156, 2016.

[6] R. Ramsenthil, and S. Dhanasekaran, "Adsorption of Chromium Using Blue Green Algae-Modeling and Application of Various Isotherm", International Journal of Chemical Technology, Vol. 10, Pp. 1-22, 2018.

[7] V.S. Tatah, O. Otitoju, and I.N.E. Onwurah, "Adsorption Isortherm and Kinetic Studies of Cd (II) and Pb (II) Ions Bioremediation from Aqueous Solution using Unmodified Bambara Groundnut Husk (Vigna Subterranean)”, AASCIT Journal of Environment, Vol. 2, No. 3, Pp. 34-42, 2017.

[8] T.A. Khan, S.A. Chaudhry, and I. Ali, “Equilibrium Uptake, Isotherm and Kinetic Studies of Cd(II) Adsorption onto Iron Oxide Activated Red Mud from Aqueous Solution", Journal of Molecular Liquid, 202, Pp. 165-175, 2015.

[9] A.A. Inyibor, F.A. Adekola, and G.A. Olatunji, "Kinetics and Isothermal Modelling of Liquid Phase Adsorption of Rhodamine B onto Urea Modified Raphia hookerie Epicarp”, Applied Water Science, Vol. 7, Pp. 3257-3266, 2017. DOI 10.1007/s13201-016-0471-7

[10] International Agency on Research for Cancer (IARC), “Monograph”, Methylene Blue., Vol 108, Pp. 155-183, 2020. available@https://monographs.iarc.fr Accessed on 16/05/2020

[11] A.B. Iliyasu, N.Y. Muhammad, I. Ali, B. Hamza, "Adsorption Studies of Delonix regia Seed Pods and Bambara Groundnut Shell on Methylene Blue Dye as Contaminant", Chemistry Research Journal, Vol. 4, No. 2, Pp. 105-122, 2019.

[16] American Standard for Testing Materials (ASTM), “Standard Test methods for Activated Carbon, available @ https://www.astm.org.standards Accessed 13/07/2018", 2012.

[29] N. Ayawei, N.A. Ebelegi, and D. Wankasi, “Modeling and Interpretation of Adsorption Isotherms”, Hindawi Journal of Chemistry, Pp. 1-11, 2017. https: //doi.org/10.1115/2017/3039817

[12] A.M. Ayuba, and T.A. Nyijime, "Paraquat Dichloride Adsorption from Aqueous Solution Using Carbonized Bambaranut (Vignea subterenean) shells", Bayero Journal of Pure and Applied Sciences, Vol. 12, No. 1, Pp. 167-177, 2019. http://dx.doi.org/10.4314/bayopas.V12i/285

[34] N. Barka, M. Abdennouri, M.E. Makhfouk, and S. Qouzal, "Biosorption Characteristics of Cd and Pb onto Eco-Friendly Dried Cactus Cladodes", Journal of Environmental and Chemistry Engineering, Vol. 1, Pp. 144-149, 2013.

[26] S.A. Bhatt, L.P. Sakaria, M. Vasudevan, R.R. Pawar, N. Sudheesh, C.H. Bajaj, and M.H. Mody, "Adsorption of an Anionic Dye from Aqueous Medium by Organoclays: Equilibrium Modelling, Kinetic and Thermodynamic Exploration", RSC Advances, Vol. 2, Pp. 8663-8671, 2012. Doi:10.1039/c2ra20347b. 
[21] A. Birtukan, S. Khalid, and M. Nathan, "Kinetic, Equilibrium and Thermodynamic Study of 2-Chlorophenol Adsorption onto Ricinus Communis Pericarp Activated Carton from Aqueous Solutions", Green Chemistry Letters and Reviews, Vol. 8, No. 3-4, Pp. 1-12, 2015. D0I:10.1$080 / 17518253.2015 .1065348$.

[17] B. Bronislaw, "Preparation of Active Carbon by Additional Activation with Potassium Hydroxide and Characterization of their Properties", Advances in Material Science and Engineering, Vol. 3, Pp. 55-59, 2016.

[30] C.H. Chakarapani, C.H. Sureshbabu, K.N.K. Vani, and R.K. Somasekhara, "Adsorption Kinetics for the Removal of Fluoride from Aqueous Solution by Activated Carbon Adsorbents Derived from the Peels of Selected Citrus Fruits”, E-Journal of Chemistry, vol. 7, Pp. 419-427, 2010.

[14] H. Dargo, N. Gabbiye, and A. Ayalew, "Removal of Methylene Blue Dye from Textile Waste Water using Activated Carbon Prepared from Rice-husk", International Journal of Innovation and Scientific Research, Vol. 9, Pp. 317-325, 2014. ISSN 2351-8014.

[15] O.A. Ekpete, A.C. Marcus, and V. Osi, "Preparation and Characterization of Activated Carbon Obtained from Plantain (Musa paradisiaca)", Journal of Chemistry, Pp. 1-6, 2017. https://doi.org/10.1155/2017/8635615.

[37] A.O. Fadali, Y. Magdy, A.A.M. Daifullah, and E.E. Ebraheim, "Removal of Chromium Tannery Effluents by Adsorption", Journal of Environmental and health Sciences Part A., Vol. 39, No. 2, Pp. 465-472, 2004. DOI:10.1081/ese-120027537

[31] R. Farouq, and N.S. Yousef, "Equilibrium and Kinetic Studies of Adsorption of Copper (II) Ions on Natural Biosorbent”, Int J. Chem. Eng. Appliances., Vol. 6, Pp. 319-324, 2015

[22] J. Guo, Y. Song, X. Ji, L. Ji, L. Cai, Y. Wang, H. Zhang, and W. Song, "Preparation and Characterization of Nanoporous Activated Carbon Derived from Prawn Shell and its Application for Removal of Heavy Metal Ions", Materials, Pp. 12, Pp. 1-17, 2019.

[19] K.D. Kowanga, E. Gatebe, and E.M. Mauti, "Kinetic Sorption Isotherms, Pseudo-First Order Model and Pseudo-Second Order Model Studies Of Cu(II) and Pb (II) Using Defatted Moriga oleifera Seed Power", Journal Of Phytopharmacology, Vol. 5, No. 2, Pp. 71-78, 2016.

[25] R. Lafi, M. Imed, and H. Amor, "Adsorption of Congo Red Dye from Aqueous Solution by Prepared Activated Carbon with Oxygen-Containing Functional Groups and its Regeneration", Adsorption Science and Technology, Vol. 37, No. 1-2, Pp. 160-181, 2019. Doi:10.1177/0263617418819227.

[35] S. Liang, X. Quo, N. Feng, and Q. Tian, "Adsorption of Cu (II) and Cd (II) from Aqueous Solution by Mercapto-Acetic Acid Modified Orange Peel”, Colloids Surfactants., B73, Pp. 10-14, 2009.

[32] N.R. Mamdouth, T.E. Kamar, H.M. Ebrahiem, and H.M. Manssour, "Adsorption of Iron and Managanese Ions Using Low Cost Materials as Adsorbent", Adsorption Science and Technology, Vol. 22, No. 1, Pp. 25-37, 2004.

[13] A.A. Manniru, S.Y. Maimuna, D. Abdulhamid, I. Abdulrahim, and Y. Salim, "Adsorption Analysis of Congo Red Dye onto the Bambaranut Shell", International Journal for Research and Development in Technology, Vol. 4, No. 5, Pp. 28-34, 2015.

[28] B.D. Mulu, "Batch Sorption Experiments: Langmuir and Freundlich Isotherm Studies for the Adsorption of Textile Metal lons onto Teff Straw (Eragrostic tef) Agricuiltural Waste”, Hindawi Journal of Thermodynamics, Pp. 1-6, 2013. http://dx.doi.org/10.1155/2013/375830.

[23] S. Nethaji, A. Sivasamy, and B. Mandal, "Adsorption Isotherms, Kinetics and Mechanism for the Adsorption of Cationic and Anionic Dyes onto Carbonaceous Particles Prepared from Juglans regia Shell Biomass", Int. J. Environmental Science Technology, Vol. 10, Pp. 231-242, 2013. Doi:10.1007/S13762-012-0112-0

[24] F. Nworie, F. Nwabue, I. Ikelle, A. Ogah, N. Elom, and N. Ilochi, “Activated Plantain Peel Biochar as Adsorbent for Sorption of Zn (II) Ions: Equilibrium and Kinetic Studies", JOTSCA, Vol. 5, No. 3, Pp. 1257-1270, 2019. Doi:http//dx.doi,org/10.18596/JOTSCA.438332.

[36] S. Panida, and F. Xianshe, "Kinetic Models on Chromium (IV) Adsorption onto Carbonized Oil Palm Kernel with Potassium Hydroxide Activation", International Journal of Advanced Chemical Engineering and Biological Science, Vol. 3, No. 1, Pp. 68-75, 2016.

[20] K. Sumanjit, R. Seema, and K.M. Rakesh, "Adsorption Kinetics for the Removal of Hazardous Dye Congo Red by Bio-waste Materials as Adsorbents", Journal of Chemistry, Pp. 1-21, 2013. http://dx.doi.org/10.1155/2013/628582.

[33] S.R. Taffarel, and R. Rubio, "Removal of Mn (II) Ions by Adsorption onto Natural and Activated Chilean Zeolites", Mineral Engineering. 22: 336-343, 2009.

[27] G. Vijayakumar, R. Tamdarsan, and M. Dharmendirakamar, "Adsorption, Kinetic, Equilibrium and Thermodynamic Studies on the Removal of Basic Dye Rhodamine-B from Aqueous Solution by the Use of Natural Adsorbent Perlite", Journal of Material and Environmental Science, Vol. 3, No. 1, Pp. $157-170,2012$. ISSN 2028-2508

[18] M.I. Yusuf, C.C. Ariahu, and B.D. Igbabul, "Production and Characterization of Activated Carbon from Selected Local Raw Materials", African Journal of Pure and Applied Chemistry, Vol. 6, No. 9, Pp. 123-131, 2012. Doi:10.5897/AJP Ac12.022. ISSN 1996-0840 